\title{
Molecular Markers in Sex Differences in Cancer
}

\author{
Ji Yoon Shin, Hee Jin Jung and Aree Moon \\ Duksung Innovative Drug Center, College of Pharmacy, Duksung Women's University, Seoul, Korea
}

\begin{abstract}
Cancer is one of the common causes of death with a high degree of mortality, worldwide. In many types of cancers, if not all, sex-biased disparities have been observed. In these cancers, an individual's sex has been shown to be one of the crucial factors underlying the incidence and mortality of cancer. Accumulating evidence suggests that differentially expressed genes and proteins may contribute to sex-biased differences in male and female cancers. Therefore, identification of these molecular differences is important for early diagnosis of cancer, prediction of cancer prognosis, and determination of response to specific therapies. In the present review, we summarize the differentially expressed genes and proteins in several cancers including bladder, colorectal, liver, lung, and nonsmall cell lung cancers as well as renal clear cell carcinoma, and head and neck squamous cell carcinoma. The sex-biased molecular differences were identified via proteomics, genomics, and big data analysis. The identified molecules represent potential candidates as sex-specific cancer biomarkers. Our study provides molecular insights into the impact of sex on cancers, suggesting strategies for sex-biased therapy against certain types of cancers.
\end{abstract}

Key words: Sex difference, Cancer, Sex hormone, Chemotherapy

\section{INTRODUCTION}

Cancer is one of the most common diseases with an extremely high mortality rate (1). Several types of cancer show sex-biased tendencies in mortality and incidence (24). Lung cancer shows the highest incidence and mortality in males, and ranks third in incidence and second in mortality among females (5). The incidence and mortality of liver cancer in males are significantly higher than in females (6). The incidence of bladder cancer is three- to four-fold higher in males than in females (7). However, females are diagnosed with more advanced disease and worse prognosis after treatment compared with males $(8,9)$. Data obtained from Korea and Japan indicate that colorectal cancer is not only associated with the highest mortality in females over 65 years of age, but also has a

Correspondence to: Aree Moon, Duksung Innovative Drug Center, College of Pharmacy, Duksung, Women's University, 33, 144gil, Samyang-ro, Dobong-gu, Seoul 01369, Korea

Email: armoon@duksung.ac.kr

This is an Open-Access article distributed under the terms of the Creative Commons Attribution Non-Commercial License (http:// creativecommons.org/licenses/by-nc/3.0) which permits unrestricted non-commercial use, distribution, and reproduction in any medium, provided the original work is properly cited. significantly higher incidence and mortality rate in females than in males over the age of 65 years (10-12). In renal clear cell carcinoma, the incidence rate was twice as common in males than in females, and males showed a lower survival rate (13). Studies investigating the role of gender and incidence or mortality in head and neck squamous cell carcinoma had no significant differences by sex (14).

Sex differences in cancer are presumably induced by sex hormones, especially estrogen (15). Sex hormones are known to modulate gene expression in many cancers (16). Sexually dimorphic expression of molecules (gene or protein) are referred to as 'sex-biased' (17-19). Sex-biased disparities in responsiveness and side effects to anticancer drugs have also been observed (reviewed in 16). For instance, the clearance of 5-fluorouracil (FU) is higher in males than in females $(20,21)$. Females treated with 5-FU showed higher levels of toxicity such as nausea, vomiting, alopecia and leukopenia than males $(21,22)$. The influence of gender on drug metabolism may contribute at least in part, to the sex-specific differences in susceptibility to anticancer drugs (23-27).

Mounting evidence suggests that genetic and molecular differences between male and female cancers may contribute to sex-biased disparities in mortality and incidence of cancers (28). For instance, male patients with lung adeno- 
carcinoma showed 1.636-fold higher frequency of genetic alterations than female patients, and greater genetic alterations were related to worse overall survival in males (29). At the genetic/molecular level, gene polymorphism and differential expression have been recognized as key factors for sex-biased differences in cancer incidence between males and females (16). However, the molecular differences between male and female cancer patients have yet to be elucidated. A comprehensive characterization of sexbiased molecular differences in cancer patients was conducted by analyzing the high-throughput molecular data obtained from The Cancer Genome Atlas (TCGA) (18).

Proteomics/genomics is one of the most efficient approaches to study the expression of proteins and genes (30). Currently, big data analytics of patient information is widely used in molecular studies. In this review, we have summarized the genes and proteins associated with sexdependent expression via approaches such as proteomics, genomics, and big data analytics in bladder, colorectal, liver, lung and non-small cell lung cancers, renal clear cell and neck squamous cell carcinoma. All these cancers except renal clear cell and head and neck squamous cell carcinoma show sex-biased incidence and mortality. This review facilitates the design of an efficient strategy for sex-specific can- cer therapy.

\section{BLADDER CANCER}

The incidence of bladder cancer is four times higher in females than in males $(31,32)$. Studies investigated the association between the risk of bladder cancer and hypomethylation of long interspersed nuclear element-1 (LINE-1) (33). The findings suggest a lower frequency of methylation of LINE-1 in females than in males. Hypomethylation of LINE-1 may be an effective biomarker for the risk of bladder cancer in females. The lowest degree of LINE1 methylation in females indicates a 2.5 -fold significantly higher risk of bladder cancer. In males, however, there was no correlation between hypomethylation of LINE-1 and risk of bladder cancer (33). Sex-biased molecules in bladder cancer are listed in Table 1.

\section{COLORECTAL CANCER}

A comparison of 54 colorectal cancer biopsies and mRNAs of adjacent normal mucosal tissues by RT-PCR analysis revealed a significant overexpression of twist family basic helix-loop-helix transcription factor 1 (TWIST1) in colorec-

Table 1. Sex-biased molecular differences in cancers

\begin{tabular}{|c|c|c|c|c|c|}
\hline \multicolumn{6}{|c|}{ Bladder cancer } \\
\hline \multirow{2}{*}{ Name } & \multicolumn{2}{|l|}{ Gender } & \multirow{2}{*}{ Method } & \multirow{2}{*}{ Reference } & \multirow{2}{*}{ Remarks } \\
\hline & Male & Female & & & \\
\hline $\begin{array}{l}\text { LINE1 } \\
\text { (Methylation) }\end{array}$ & & - & $\begin{array}{l}\text { Quantitative Bisulfite } \\
\text { Pyrosequencing }\end{array}$ & 33 & $\begin{array}{l}\text { Hypomethylation of LINE1 in females } \\
\text { indicates higher risk of bladder cancer. } \\
\text { No relation in male. }\end{array}$ \\
\hline \multicolumn{6}{|c|}{-: Low frequency of methylation related to bladder cancer } \\
\hline \multicolumn{6}{|c|}{ Colorectal cancer } \\
\hline \multirow{2}{*}{ Name } & \multicolumn{2}{|l|}{ Gender } & \multirow{2}{*}{ Method } & \multirow{2}{*}{ Reference } & \multirow{2}{*}{ Remarks } \\
\hline & Male & Female & & & \\
\hline $\mathrm{ER} \alpha$ & + & & \multirow[t]{2}{*}{ Immunoblot assay } & \multirow[t]{2}{*}{42} & $\begin{array}{l}\text { Significantly increased in tumor tissue than } \\
\text { normal tissue of male. } \\
\text { No alteration in female. }\end{array}$ \\
\hline $\mathrm{ER} \beta$ & - & -- & & & $\begin{array}{l}\text { Significantly decreased in tumor tissue of } \\
\text { female than male. }\end{array}$ \\
\hline \multirow{2}{*}{$\begin{array}{l}\text { K-ras } \\
\text { (Point mutations) }\end{array}$} & $\begin{array}{c}- \\
\text { (younger male) }\end{array}$ & & \multirow{2}{*}{$\begin{array}{c}\text { Sequence-specific } \\
\text { Oligonucleotide probes }\end{array}$} & \multirow{2}{*}{41} & \multirow{2}{*}{$\begin{array}{l}\text { More frequent mutations in older male than } \\
\text { older female. }\end{array}$} \\
\hline & $\begin{array}{c}+ \\
\text { (older male) }\end{array}$ & & & & \\
\hline $\begin{array}{l}\text { p16INK4a } \\
\text { (Methylation) }\end{array}$ & & + & $\begin{array}{l}\text { Methylation-specific } \\
\text { PCR analysis }\end{array}$ & 44 & \\
\hline TWIST1 & + & & RT-PCR analysis & 34 & \\
\hline \multicolumn{6}{|c|}{$\begin{array}{l}\text { +: High expression/point mutation/methylation related to colorectal cancer } \\
\text {-: Low expression/point mutation related to colorectal cancer } \\
\text {--: Very low expression/point mutation related to colorectal cancer }\end{array}$} \\
\hline
\end{tabular}


Table 1. Continued

\begin{tabular}{|c|c|c|c|c|c|}
\hline \multicolumn{6}{|c|}{ Head and neck squamous cell carcinoma } \\
\hline \multirow{2}{*}{ Name } & \multicolumn{2}{|c|}{ Gender } & \multirow{2}{*}{ Method } & \multirow{2}{*}{ Reference } & \multirow{2}{*}{ Remarks } \\
\hline & Male & Female & & & \\
\hline Claudin-7 & \multirow{2}{*}{+} & & \multirow{11}{*}{$\begin{array}{l}\text { Big data analytics } \\
\text { (TCGA) }\end{array}$} & \multirow{11}{*}{17} & \multirow{2}{*}{ Higher expression in male } \\
\hline Smad4 & & & & & \\
\hline $\mathrm{Bad}$ & & \multirow{9}{*}{+} & & & \multirow{9}{*}{ Higher expression in female } \\
\hline GSK-3-alpha-beta & & & & & \\
\hline HER2 & & & & & \\
\hline MAPK & & & & & \\
\hline p38 & & & & & \\
\hline PDCD4 & & & & & \\
\hline Rictor & & & & & \\
\hline Src_pY416 & & & & & \\
\hline YAP & & & & & \\
\hline \multicolumn{6}{|c|}{ +: High expression related to head and neck squamous cell carcinoma } \\
\hline \multicolumn{6}{|c|}{ Liver cancer } \\
\hline \multirow{2}{*}{ Name } & \multicolumn{2}{|c|}{ Gender } & \multirow{2}{*}{ Method } & \multirow{2}{*}{ Reference } & \multirow{2}{*}{ Remarks } \\
\hline & Male & Female & & & \\
\hline ATP6V0B & \multirow{12}{*}{+} & & \multirow{12}{*}{$\begin{array}{l}\text { Oligonucleotide } \\
\text { microarray }\end{array}$} & \multirow{12}{*}{46} & \multirow{9}{*}{ Higher expression in male } \\
\hline BLVRB & & & & & \\
\hline IFNAR1 & & & & & \\
\hline MTHFD1 & & & & & \\
\hline NNT & & & & & \\
\hline PRDX1 & & & & & \\
\hline SMARCA2 & & & & & \\
\hline SOD1 & & & & & \\
\hline ZNF33B & & & & & \\
\hline HUM3BMCP & & & & & \\
\hline JARIDID & & & & & Located in the $\mathrm{Y}$ chromosome \\
\hline RPS4Y & & & & & \\
\hline CYP1A2 & \multirow{3}{*}{+} & & \multirow{3}{*}{ Enzyme activity } & & \\
\hline CYP2C16 & & & & $53-55$ & Higher activity in male \\
\hline CYP2D6 & & & & & \\
\hline CDK6 & & & & & \\
\hline FGFR2 & & & & & \\
\hline FLJ20489 & & & & & \\
\hline FGFR3 & & & & & \\
\hline HSHRTPSN & & + & Oligonucleotide & 46 & Higher expression in female \\
\hline MFAP & & & microarray & T0 & 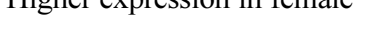 \\
\hline polyA site & & & & & \\
\hline PRDX3 & & & & & \\
\hline PROL2 & & & & & \\
\hline RPS4X & & & & & \\
\hline
\end{tabular}


Table 1. Continued

\begin{tabular}{|c|c|c|c|c|c|}
\hline \multicolumn{6}{|c|}{ Liver cancer (continued) } \\
\hline \multirow{2}{*}{ Name } & \multicolumn{2}{|c|}{ Gender } & \multirow{2}{*}{ Method } & \multirow{2}{*}{ Reference } & \multirow{2}{*}{ Remarks } \\
\hline & Male & Female & & & \\
\hline ARSE & & \multirow{5}{*}{+} & \multirow{5}{*}{$\begin{array}{l}\text { Oligonucleotide } \\
\text { microarray }\end{array}$} & \multirow{5}{*}{46} & \multirow{5}{*}{ Located in the $\mathrm{X}$ chromosome } \\
\hline DDX3X & & & & & \\
\hline E1F1AX & & & & & \\
\hline USP9X & & & & & \\
\hline XIST & & & & & \\
\hline CYP3A4 & & + & Enzyme activity & 51 & Higher activity in female \\
\hline \multicolumn{6}{|c|}{$+:$ High expression related to liver cancer } \\
\hline \multicolumn{6}{|c|}{ Lung cancer and non-small cell lung cancer } \\
\hline \multirow{2}{*}{ Name } & \multicolumn{2}{|c|}{ Gender } & \multirow{2}{*}{ Method } & \multirow{2}{*}{ Reference } & \multirow{2}{*}{ Remarks } \\
\hline & Male & Female & & & \\
\hline sFAS & \multirow{4}{*}{+} & & \multirow{4}{*}{$\begin{array}{l}\text { Proteomics } \\
\text { (multiplex } \\
\text { immunoassays and } \\
\text { mass spectrometry) }\end{array}$} & \multirow{4}{*}{57} & \multirow{4}{*}{ Higher expression in male } \\
\hline MMP-9 & & & & & \\
\hline PAI-1 & & & & & \\
\hline CD40 & & + & & & \\
\hline EGFR & & \multirow[t]{2}{*}{+} & \multirow[t]{2}{*}{ Immunohistochemistry } & 56 & $\begin{array}{l}\text { May be related to a higher response to } \\
\text { anticancer drugs in female patients }\end{array}$ \\
\hline PTHrP & & & & 59 & Significant predictor of survival for female \\
\hline \multicolumn{6}{|c|}{ +: High expression related to lung cancer and non-small cell lung cancer } \\
\hline \multicolumn{6}{|c|}{ Renal clear cell carcinoma } \\
\hline \multirow{2}{*}{ Name } & & & Mothod & Doforonco & Domprto \\
\hline & Male & Female & tviction & 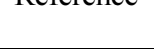 & 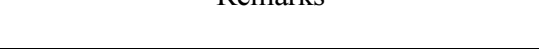 \\
\hline AR & & & & & \\
\hline ARHJ & & & & & \\
\hline IRS1 & & & & & \\
\hline JAB1 & & & & & \\
\hline PAI-1 & + & & & & Higher expression in male \\
\hline PKC-alpha & & & & & \\
\hline Transglutaminase & & & & & \\
\hline VEGFR2 & & & & & \\
\hline VHL & & & Big data analytics & 17 & \\
\hline 4E-BP1 & & & (TCGA) & 17 & \\
\hline Akt & & & & & \\
\hline DJ-1 & & & & & \\
\hline NDRG1 & & & & & \\
\hline p38 & & + & & & Higher expression in female \\
\hline PTEN & & & & & \\
\hline Src & & & & & \\
\hline VEGFR2 & & & & & \\
\hline VHL & & & & & \\
\hline
\end{tabular}


tal cancer samples compared with benign colon mucosa and a significant increase in patients with nodal invasion (34). TWIST1 is involved in the regulation of epithelialmesenchymal transition (EMT), inducing cancer progression and metastasis, in various cancers (35-37). Notably, the expression of TWIST1 mRNA was higher in males than in females, suggesting the possibility of differential transcriptional regulation of TWIST1 by sex hormones (34).

In early stage of colorectal carcinogenesis, KRAS mutations were observed in $27-43 \%$ of patients (38-40). DNA from 251 primary tumors of Norwegian patients with colorectal carcinoma was analyzed using sequence-specific oligonucleotide probes for the presence of k-ras point mutations at codons 12 and 13 (41). Male patients younger than 40 years carried fewer k-ras mutations in colon tumors compared with female patients (41). This finding suggested dominance of ras-independent pathways of colon cancer in younger males (41). In contrast, older males carried a higher number of k-ras mutations than older females (41).

The expression of ER $\alpha$ and $E R \beta$ protein showed no sex differences between normal colon mucosal tissues; however, significant differences were observed between tumor tissues (42). The ER $\alpha$ protein expression was significantly increased in tumor tissues of male patients compared with normal tissues (42). By contrast, the ER $\alpha$ level did not differ between tumor tissues and normal tissues of female patients (42). The level of ER $\beta$ protein and mRNA was significantly reduced in both male and female patients diagnosed with colon cancer, although a greater decrease was observed in males $(42,43)$. The ER $\beta$ level was decreased in poorly differentiated tumors of males (42).

Colorectal cancer associated with the proximal colon in females may show a different disease subtype (44). In 120 sporadic colorectal cancers, methylation-specific PCR was performed to determine whether the methylation of the $\mathrm{CpG}$ island in the $5^{\prime}$ region of the $\mathrm{p} 16^{\mathrm{INK} 4 \mathrm{a}}$ tumor suppressor gene was associated with sex or other clinicopathological characteristics. In female patients, methylation-positive cancer was 8.8-fold higher than in male patients, and methylation of $\mathrm{p} 16^{\mathrm{INK} 4 \mathrm{a}}$ was associated with poorly differentiated tumors. Female patients with $\mathrm{p} 16^{\mathrm{INK} 4 \mathrm{a}}$ methylation may represent an important database of molecular alterations associated with sporadic colorectal cancers (44). Sex-biased molecular differences in colorectal cancer are listed in Table 1.

\section{HEAD AND NECK SQUAMOUS CELL CARCINOMA}

Abundant signals associated with sex-biased protein expression in head and neck squamous cell carcinoma were detected via TCGA database analysis (18). In patients with head and neck squamous cell carcinoma, 12 of 15 sex- biased proteins were identified, and the expression of Yes associated protein (YAP), programmed cell death 4 (PDCD4), glycogen synthase kinase $3(\mathrm{GSK} 3-\alpha / \beta)$, mitogen-activated protein kinase (MAPK), Src, p38, human epidermal growth factor receptor 2 (HER2), B cell leukemia/lymphoma (BCL2) associated agonist of cell death (Bad), and Rictor were upregulated in females whereas Claudin-7 and Smad4 were upregulated in males (18). SRC plays an important role in regulating a variety of cellular signal transduction pathways. The SRC kinase pathways are frequently activated in many carcinomas, especially metastatic diseases (45). In head and neck squamous cell carcinoma, SRC kinase may be the key molecule that shows a potential to be a female-specific prognosis marker. Sex-biased molecular differences in head and neck squamous cell carcinoma are listed in Table 1.

\section{LIVER CANCER}

In hepatocellular carcinoma, 27 genes were identified from male $(n=34)$ and female $(n=16)$ hepatocellular carcinoma patient tissue mRNAs, which showed sex-specific differential expression (46). Among these genes, 12 showed higher and 15 lower levels of expression in males compared with females. Among the 12 genes expressed higher in male samples, interferon ( $\alpha$ and $\beta$ ) receptor 1 (IFNAR1), ATPase $\mathrm{H}+$ transporting V0 subunit b (ATP6V0B), biliverdin reductase $\mathrm{B}$ (BLVRB), zinc finger protein 33B (ZNF33B), nicotinamide nucleotide transhydrogenase (NNT), methylenetetrahydrofolate dehydrogenase, cyclohydrolase and formyltetrahydrofolate synthetase 1 (MTHFD1), superoxide dismutase 1 (SOD1), SWI/SNF related, matrix associated, actin dependent regulator of chromatin, subfamily a, member 2 (SMARCA2) and peroxide peroxidase 1 (PRDX1) were located on the autosome while ribosomal protein S4 Y-linked 1 (RPS4Y), lysine demethylase 5D (JARIDID), and HUM3BMCP were located on the $Y$ chromosome. PRDX1 and SOD1 were highly expressed in male hepatocellular carcinoma samples (46). In hepatocellular carcinoma, PRDX1 may be a key molecule for sex-biased mortality and incidence. PRDX, a major component of antioxidant enzymes, removes reactive oxygen species (47). PRDX1 is a versatile molecule that regulates cell growth, differentiation, cell death and tumor suppression $(48,49)$. However, the 15 genes with a higher expression in female samples include cyclin dependent kinase 6 (CDK6), PROL2, FLJ20489, fibroblast growth factor receptor 2 (FGFR2), microfibrillar-associated protein 2 (MFAP), peroxiredoxin 3 (PRDX3), fibroblast growth factor receptor 3 (FGFR3), polyA site, and HSHRTPSN located on the autosome, and inactive X specific transcripts (XIST), ubiquitin specific peptidase 9 X-linked (USP9X), E1F1AX, ribosomal protein S4 X-linked (RPS4X), arylsulfatase E (ARSE), and DEAD-box helicase $3 \mathrm{X}$-linked (DDX3X) 
on the X chromosome (46).

Sex differences in the gene expression of drug metabolizing enzymes and transporters result in differences in drug absorption, distribution, metabolism and excretion, possibly affecting drug efficacy and adverse reactions (50). Cytochrome P450 family 3 subfamily A member 4 (CYP3A4) is an enzyme that is responsible for the metabolism of over $50 \%$ of all therapeutic drugs $(51,52)$. Higher CYP3A4 activity was observed in females than in males; by contrast, higher activities of cytochrome P450 family 1 subfamily A member 2 (CYP1A2), cytochrome P450 2C16 (CYP2C16), cytochrome P450 family 2 subfamily D member 6 (CYP2D6) and cytochrome P450 family 2 subfamily E member 1 (CYP2E1) were detected in males than in females (53-55). The analysis of enzymatic activity in human liver microsomes and hepatocytes revealed no significant differences in hepatic CYP3A4 activity between males and females (50). However, in primary hepatocytes, a two-fold higher activity of CYP3A4 was observed in females than in males (51). Sex-biased molecular differences in liver cancer are listed in Table 1.

\section{LUNG CANCER AND NON-SMALL CELL LUNG CANCER}

Epidermal growth factor receptor (EGFR), the most important therapeutic target in lung cancer, was specifically expressed in females (18). Erlotinib and gefitinib are the major anti-cancer drugs that target EGFR pathway in lung cancer (56). Female patients showed higher response to erlotinib than male patients (56). This higher response among female patients may be related to a higher expression of EGFR observed in females $(18,56)$.

Sex-specific biomarkers were identified in non-small cell lung cancer, using multiplex immunoassays and mass spectrometry (57). In males, soluble Fas (sFAS), matrix metalloproteinase-9 (MMP-9), and plasminogen activator inhibitor-1 (PAI-1) were strongly predictive biomarkers, whereas soluble cluster of differentiation 40 (sCD40) was prognostic for cancers in females (57). The factors underlying these gender-biased differences in non-small cell lung cancer are not clear. Studies to date indicate that these proteins play different roles in male and female patients due to endocrine differences.

Parathyroid hormone-related protein (PTHrP) is upregulated in tumors with skeletal metastasis and commonly expressed in non-small cell lung carcinomas $(58,59)$. Female patients diagnosed with non-small cell lung carcinoma with and without PTHrP showed a median survival of 55 and 22 months, respectively, whereas male survival was independent of PTHrP status for 38 months. PTHrP was suggested as a significant predictor of survival in female patients after adjusting for stage, age, and histology (59). Sex-biased molecular differences in lung cancer and non- small cell lung cancer are listed in Table 1.

\section{RENAL CLEAR CELL CARCINOMA}

Using TCGA database analytics, sex-biased proteins from renal clear cell carcinoma were analyzed (18). In renal clear cell carcinoma, 18 out of 25 proteins were upregulated in females. These include N-myc downstream regulated 1 (NDRG1), Akt, phosphatase and tensin homolog (PTEN), DJ-1, 4E binding protein 1 (4E-BP1), Src, and p38. The von Hippel-Lindau (VHL), phosphoribosylanthranilate isomerase 1 (PAI-1), PKC-alpha, VEGFR2, androgen receptor (AR), ARHJ, insulin receptor substrate 1 (IRS1), C-Jun activation domain-binding protein-1 (JAB1) genes were upregulated in males (18). Sex-biased molecular differences in renal clear cell carcinoma are listed in Table 1.

\section{SEX-BIASED MOLECULES IN ANIMAL CANCERS}

Large portions of genome in animals are shown to be sex-specific. Sex-biased gene expression may increase the differences between female and male development, to facilitate adaptive sex differentiation in vivo (60-62). The genomic distribution of sex-biased genes (i.e., chromosomal binding patterns) in animals also provides clues to the evolutionary process and the underlying genetic variation in development according to sex $(63,64)$. Mice and rats are frequently used for cancer research (65). In this review, we have summarized the sex-biased molecular differences in animal cancers.

Recently, a Hras 12V transgenic mouse model was generated to demonstrate the development of male-biased hepatic tumorigenesis (66). The peritumor and tumoral tissues of male and female transgenic mice were compared with normal liver tissues of non-transgenic mice via proteomic analysis. During hepatic tumorigenesis, 19 proteins derived from males and 10 proteins from female mice showed sex-biased expression (66). The upregulated proteins in males were Rho GDP dissociation inhibitor alpha (ARHGDIA), fatty acid binding protein 1 (FABP1), nucleophosmin 1 (NPM1), ribosomal protein lateral stalk subunit P2 (RPLP2), dihydrodiol dehydrogenase (DHDH), ATP5D, farnesyl diphosphate synthase (FDPS), and ubiquilin 1 (UBQLN1). The proteins involved in DNA packing include Histone $\mathrm{H} 4$, Histone $\mathrm{H} 2 \mathrm{AA}$, and Histone $\mathrm{H} 2 \mathrm{AB}$. SFL2, protein disulfide isomerase family A member 6 (PDIA6), tropomyosin 1 (TPM1) were also upregulated in a male-specific manner (66). Female-specific proteins such as acyl-CoA oxidase 1 (ACOX1), adenosylhomocysteinase (AHCY), betaine-homocysteine S-methyltransferase 2 (BHMT2), glutathione S-transferase alpha 3 (GSTA3), basonuclin 2 (BNC2), calmodulin 1 (CALM1), and profiling 1 (PFN1) were downregulated (66). However, apolipoprotein A4 (APOA4), eukaryotic translation elongation 
factor 2 (Eef2), and heat shock protein family A member 8 (HSPA8) were upregulated in females. The metabolic category of proteins including aldehyde dehydrogenase 1 family member L1 (ALDH1L1), phosphoglycerate kinase 1 (PGK1), and sterol carrier protein 2 (SCP2) were downregulated in males. Glutathione peroxidase 1 (GPX1), peroxiredoxin 6 (PRDX6), cytochrome b5 type A (CYB5A), and heat shock protein family E member 1 (HSPE1) showed a reversal of expression in males and females (66).

To study the effects of forkhead box A1 (FOXA1), a member of the forkhead class of DNA-binding proteins, on liver cancer production, liver tumors were induced in female and male controls and liver-specific FOXA1/2deficient mice (67). These hepatocyte nuclear factors are

Table 2. Sex-biased molecules in animal liver cancers

\begin{tabular}{|c|c|c|c|c|c|}
\hline \multirow{2}{*}{ Gene name } & \multicolumn{2}{|c|}{ Gender } & \multirow{2}{*}{ Method } & \multirow{2}{*}{ Reference } & \multirow{2}{*}{ Remarks } \\
\hline & Male & Female & & & \\
\hline ARHGDIA & \multirow{14}{*}{+} & & \multirow{14}{*}{$\begin{array}{l}\text { Proteomics (2D-Fluorescence } \\
\text { difference gel electrophoresis), } \\
\text { genetics, and immunoblot assay }\end{array}$} & \multirow{14}{*}{66} & \multirow{16}{*}{ No significance in female } \\
\hline ATP5D & & & & & \\
\hline DHDH & & & & & \\
\hline FABP1 & & & & & \\
\hline FDPS & & & & & \\
\hline Histone $\mathrm{H} 2 \mathrm{AA}$ & & & & & \\
\hline Histone $\mathrm{H} 2 \mathrm{AB}$ & & & & & \\
\hline Histone $\mathrm{H} 4$ & & & & & \\
\hline NPM1 & & & & & \\
\hline PDIA6 & & & & & \\
\hline RPLP2 & & & & & \\
\hline SFL2 & & & & & \\
\hline TPM1 & & & & & \\
\hline UBQLN1 & & & & & \\
\hline FOXA1 & \multirow{2}{*}{+} & & \multirow{2}{*}{$\begin{array}{l}\text { Chromatin Immunoprecipitation } \\
\text { (ChIP) assays }\end{array}$} & \multirow{2}{*}{67} & \\
\hline FOXA2 & & & & & \\
\hline p53 & \multirow{3}{*}{+} & \multirow{3}{*}{-} & \multirow{3}{*}{$\begin{array}{l}\text { Immunoblot assay, RT-PCR } \\
\text { analysis, and microarray }\end{array}$} & \multirow{3}{*}{68} & \multirow{3}{*}{ Higher expression in male } \\
\hline Pten & & & & & \\
\hline $\mathrm{Rb}$ & & & & & \\
\hline APOA4 & \multirow{6}{*}{-} & \multirow{3}{*}{+} & \multirow{13}{*}{$\begin{array}{l}\text { Proteomics (2D-Fluorescence } \\
\text { difference gel electrophoresis), } \\
\text { genetics, and immunoblot assay }\end{array}$} & \multirow{13}{*}{66} & \multirow{3}{*}{ No significance in male } \\
\hline Eef2 & & & & & \\
\hline HSPA8 & & & & & \\
\hline ALDH1L1 & & & & & \\
\hline PGK1 & & & & & No significance in female \\
\hline $\mathrm{SCP} 2$ & & & & & \\
\hline ACOX1 & & \multirow{7}{*}{ - } & & & \multirow{7}{*}{ No significance in male } \\
\hline AHCY & & & & & \\
\hline BHMT2 & & & & & \\
\hline $\mathrm{BNC2}$ & & & & & \\
\hline CALM1 & & & & & \\
\hline GSTA3 & & & & & \\
\hline PFN1 & & & & & \\
\hline
\end{tabular}


transcriptional activators of liver-specific transcripts such as albumin and transthyretin, and interact with chromatin as pioneering factors. After treatment with carcinogens, large and diverse tumors were detected in the females with FOXA1/2 deficiency, whereas tumor growth in male mutants was reduced compared with the control. Thus, the expression of FOXA-specific genes in mice seems to be related to the prognosis of hepatocellular carcinoma. It was suggested that FOXA1 and FOXA2 may promote hepatocellular carcinoma in male mice, while protecting female mice against hepatocellular carcinoma (67).

The expression of tumor suppressor genes (PTEN, p53 and $\mathrm{Rb}$ ) was down-regulated in the early stages of female glycine N-methyltransferase (Gnmt)-/- mice, but not in male mice (65). The GNMT mediating 1-carbon metabolism affects DNA methylation by controlling the ratio of S-adenosylmethionine to S-adenosylmorphine $(68,69)$. These data suggest that Gnmt deficiency not only increases the expression of tumor genes but also induces a decrease in the expression of other tumor suppressor genes in the early stages of tumorigenesis in female rats, which explains the higher risk of hepatocellular carcinoma in female Gnmt-/mice (67). The sex-biased molecules are listed in Table 2.

\section{CONCLUSIONS}

We have summarized the molecules that are differentially expressed between males and females in bladder cancer, colorectal cancer, liver cancer, lung cancer, non-small cell lung cancer, and head and neck squamous cell carcinoma and renal clear cell carcinoma. The sex-biased molecular differences in cancers are listed in Table 1 and 2. Molecular differences include sex-specific upregulation or downregulation of proteins and mRNAs, frequency of gene methylation, and activity of enzymes.

Sex-specific cancer therapies are indicated according to the differential role played by sex-biased molecular expression in oncology and pharmacology. Nevertheless, sexspecific follow-up clinical trials beyond sex hormone-specific therapy remain at an early stage (70). Many clinical and pre-clinical results suggest that sex and gender differences may affect drug-promoted pathological states such as drug digestion and drug dependence or addiction. Gender differences in drug pharmacodynamics and pharmacokinetics will also affect drug addiction, dependence and side effects $(71,72)$. Efforts are needed to evaluate the clinical utility of sex-biased target therapies in a larger range of patient cohorts (70). There is still a lack of biologic relevance of cancer diagnosis, prognosis, severity, and prediction of response to treatment. Genomics studies showed a variation in the expression of autosomal genes between males and females (71). We believe that this variation may affect sex-specific cancer prognosis. Metabolomics studies also revealed gender differences in metabolite levels and their correlations with genetic markers (72).

Mechanisms underlying the differential expression of molecules in male and female cancers remain to be elucidated. Further investigation into the association of these molecules with sex-specific incidence and mortality of cancers is also needed. Our review elucidates the molecular differences to facilitate the identification of sex-specific cancer biomarkers.

\section{ACKNOWLEDGMENTS}

This study was supported by the Duksung Women's University Research Grant 2018.

\section{CONFLICT OF INTEREST}

The authors have no conflict of interest to disclose.

Received July 3, 2019; Revised July 5, 2019; Accepted July 10,2019

\section{REFERENCES}

1. Jemal, A., Bray, F., Center, M.M., Ferlay, J., Ward, E. and Forman, D. (2011) Global cancer statistics. CA Cancer J. Clin., 61, 69-90.

2. Cook, M.B., McGlynn, K.A., Devesa, S.S., Freedman, N.D. and Anderson, W.F. (2011) Sex disparities in cancer mortality and survival. Cancer Epidemiol. Biomarkers Prev., 20, 1629-1637.

3. Siegel, R.L., Miller, K.D. and Jemal, A. (2016) Cancer statistics. CA Cancer J. Clin., 66, 7-30.

4. Fitzmaurice, C., Allen, C., Barber, R.M., Barregard, L., Bhutta, Z.A., Brenner, H., Dicker, D.J., Chimed-Orchir, O., Dandona, R., Dandona, L., Fleming, T., Forouzanfar, M.H., Hancock, J., Hay, R.J., Hunter-Merrill, R., Huynh, C., Hosgood, H.D., Johnson, C.O., Jonas, J.B., Khubchandani, J., Kumar, G.A., Kutz, M., Lan, Q., Larson, H.J., Liang, X., Lim, S.S., Lopez, A.D., MacIntyre, M.F., Marczak, L., Marquez, N., Mokdad, A.H., Pinho, C., Pourmalek, F., Salomon, J.A., Sanabria, J.R., Sandar, L., Sartorius, B., Schwartz, S.M., Shackelford, K.A., Shibuya, K., Stanaway, J., Steiner, C., Sun, J., Takahashi, K., Vollset, S.E., Vos, T., Wagner, J.A., Wang, H., Westerman, R., Zeeb, H., Zoeckler, L., Abd-Allah, F., Ahmed, M.B., Alabed, S., Alam, N.K., Aldhahri, S.F., Alem, G., Alemayohu, M.A., Ali, R., Al-Raddadi, R., Amare, A., Amoako, Y., Artaman, A., Asayesh, H., Atnafu, N., Awasthi, A., Saleem, H.B., Barac, A., Bedi, N., Bensenor, I., Berhane, A., Bernabé, E., Betsu, B., Binagwaho, A., Boneya, D., Campos-Nonato, I., Castañeda-Orjula, C., Catalá-López, F., Chiang, P., Chibueze, C., Chitheer, A., Choi, J.Y., Cowie, B., Damtew, S., das, N.J., Dey, S., Dharmaratne, S., Dhillon, P., Ding, E., Driscoll, T., Ekwueme, D., Endries, A.Y., Farvid, M., Farzadfar, F., Fernandes, J., Fischer, F., G/Hiwot, T.T., Gebru, A., Gopalani, S., Hailu, A., Horino, M., Horita, N., Husseini, A., Huybrechts, I., Inoue, M., Islami, F., Jakovljevic, M., James, S., Javanbakht, M., Jee, S.H., Kasaeian, A., 
Kedir, M.S., Khader, Y.S., Khang, Y.H., Kim, D., Leigh, J., Linn, S., Lunevicius, R., El Razek, H.M.A., Malekzadeh, R., Malta, D.C., Marcenes, W., Markos, D., Melaku, Y.A., Meles, K.G., Mendoza, W., Mengiste, D.T., Meretoja, T.J., Miller, T.R., Mohammad, K.A., Mohammadi, A., Mohammed, S., Moradi-Lakeh, M., Nagel, G., Nand, D., Le Nguyen, Q., Nolte, S., Ogbo, F.A., Oladimeji, K.E., Oren, E., Pa, M., Park, E.K., Pereira, D.M., Plass, D., Qorbani, M., Radfar, A., Rafay, A., Rahman, M., Rana, S.M., Søreide, K., Satpathy, M., Sawhney, M., Sepanlou, S.G., Shaikh, M.A., She, J., Shiue, I., Shore, H.R., Shrime, M.G., So, S., Soneji, S., Stathopoulou, V., Stroumpoulis, K., Sufiyan, M.B., Sykes, B.L., Tabarés-Seisdedos, R., Tadese, F., Tedla, B.A., Tessema, G.A., Thakur, J.S., Tran, B.X., Ukwaja, K.N., Uzochukwu, B.S.C., Vlassov, V.V., Weiderpass, E., Wubshet, T.M., Yebyo, H.G., Yimam, H.H., Yonemoto, N., Younis, M.Z., Yu, C., Zaidi, Z., Zaki, M.E.S., Zenebe, Z.M., Murray, C.J.L. and Naghavi, M. (2017) Global, regional, and national cancer incidence, mortality, years of life lost, years lived with disability, and disability-adjusted life-years for 32 cancer groups, 1990 to 2015: a systematic analysis for the global burden of disease study. JAMA Oncol., 3, 524-548.

5. Bray, F., Ferlay, J., Soerjomataram, I., Siegel, R.L., Torre. L.A. and Jemal, A. (2018) Global cancer statistics 2018: GLOBOCAN estimates of incidence and mortality worldwide for 36 cancers in 185 countries. CA Cancer J. Clin., 68, 394-424.

6. Hefaiedh, R., Ennaifer, R., Romdhane, H., Ben, N.H., Arfa, N., Belhadj, N., Gharbi, L. and Khalfallah, T. (2013) Gender difference in patients with hepatocellular carcinoma. Tunis Med., 91, 505-508.

7. Dobruch, J., Daneshmand, S., Fisch, M., Lotan, Y., Noon, A.P., Resnick, M.J., Shariat, S.F., Zlotta, A.R. and Boorjian, S.A. (2016) Gender and bladder cancer: a collaborative review of etiology, biology, and outcomes. Eur. Urol., 69, 300-310.

8. Horstmann, M., Witthuhn, R., Falk, M. and Stenzl, A. (2008) Gender-specific differences in bladder cancer: a retrospective analysis. Gend. Med., 5, 385-394.

9. Shariat, S.F., Sfakianos, J.P., Droller, M.J., Karakiewicz, P.I., Meryn, S. and Bochner, B.H.. (2010) The effect of age and gender on bladder cancer: a critical review of the literature. BJU Int., 105, 300-308.

10. Jung, K.W., Won, Y.J., Kong, H.J., Oh, C.M., Cho, H., Lee, D.H. and Lee, K.H. (2015) Cancer statistics in Korea: incidence, mortality, survival, and prevalence in 2012. Cancer Res. Treat., 47, 127-141.

11. Matsuda, A., Matsuda, T., Shibata, A., Katanoda, K., Sobue, T. and Nishimoto, H. (2008) Cancer incidence and incidence rates in Japan in 2008: a study of 25 population-based cancer registries for the Monitoring of Cancer Incidence in Japan (MCIJ) project. Jpn. J. Clin. Oncol., 44, 388-396.

12. Ferlay, J., Ervik, M., Dikshit, R., Eser, S., Mathers, C., Rebelo, M., Parkin, D.M., Forman, D. and Bray, F. (2015) Cancer incidence and mortality worldwide: sources, methods and major patterns in GLOBOCAN 2012. Int. J. Cancer, 136, 359-386.

13. Stafford, H.S., Saltzstein, S.L., Shimasaki, S., Sanders, C., Downs, T.M. and Sadler, G.R. (2008) Racial/ethnic and gen- der disparities in renal cell carcinoma incidence and survival. J. Urol., 179, 1704-1708.

14. Roberts, J.C., Li, G., Reitzel, L.R., Wei, Q. and Sturgis, E.M. (2010) No evidence of sex-related survival disparities among head and neck cancer patients receiving similar multidisciplinary care: a matched-pair analysis. Clin. Cancer Res., 16, 5019-5027.

15. Özdemir, B.C. and Dotto, G.P. (2019) Sex hormones and anticancer immunity. Clin. Cancer Res. doi: 10.1158/10780432.CCR-19-0137 [Epub ahead of print].

16. Kim, H.I., Lim, H. and Moon, A. (2018) Sex differences in cancer: epidemiology, genetics and therapy. Biomol. Ther. (Seoul), 26, 335-342.

17. Cui, C., Yang, W., Shi, J., Zhou, Y., Yang, J., Cui, Q. and Zhou, Y. (2018) Identification and analysis of human sexbiased microRNAs. Genomics Proteomics Bioinformatics, 16, 200-211.

18. Yuan, Y., Liu, L., Chen, H., Wang, Y., Xu, Y., Mao, H., Li, J., Mills, G.B., Shu, Y., Li, L. and Liang, H. (2016) Comprehensive characterization of molecular differences in cancer between male and female patients. Cancer Cell., 29, 711722 .

19. Ellegren, H. and Parsch, J. (2007) The evolution of sexbiased genes and sex-biased gene expression. Nat. Rev. Genet., 8, 689-698.

20. Milano, G., Etienne, M.C., Cassuto-Viguier, E., Thyss, A., Santini, J., Frenay, M., Renee, N., Schneider, M. and Demard, F. (1992) Influence of sex and age on fluorouracil clearance. J. Clin. Oncol., 10, 1171-1175.

21. Sloan, J.A., Goldberg, R.M., Sargent, D.J., Vargas-Chanes, D., Nair, S., Cha, S.S., Novotny, P.J., Poon, M.A., O'Connell, M.J. and Loprinzi, C.L. (2002) Women experience greater toxicity with fluorouracil-based chemotherapy for colorectal cancer. J. Clin. Oncol., 20, 1491-1498.

22. Lim, H., Kim, S.Y., Lee, E., Lee, S., Oh, S., Jung, J., Kim, K.S. and Moon, A. (2019) Sex-dependent adverse drug reactions to 5-fluorouracil in colorectal cancer. Biol. Pharm. Bull., 42, 594-600.

23. Giudicelli, J.F. and Tillement, J.P. (1977) Influence of sex on drug kinetics in man. Clin. Pharmacokinet., 2, 157-166.

24. Wilson, K. (1984) Sex-related differences in drug disposition in man. Clin. Pharmacokinet., 9, 189-202.

25. Bonate, P.L. (1991) Gender-related differences in xenobiotic metabolism. J. Clin Pharmacol., 31, 684-690.

26. Harris, J.R., Tambs, K. and Magnus, P. (1995) Sex-specific effects for body mass index in the new Norwegian twin panel. Genet. Epidemiol., 12, 251-265.

27. Xie, Y., Miller, G.G., Cubitt, S.A., Soderlind, K.J., AllalunisTurner, M.J. and Lown, J.W. (1997) Enediyne-lexitropsinDNA-targeted anticancer agents. Physicochemical and cytotoxic properties in human neoplastic cells in vitro, and intracellular distribution. Anticancer Drug Des., 12, 169179.

28. Dorak, M.T. and Karpuzoglu, E. (2012) Gender differences in cancer susceptibility: an inadequately addressed issue. Front. Genet., 3, 268-276.

29. Xiao, D., Pan, H., Li, F., Wu, K., Zhang, X. and He, J. (2016) Analysis of ultra-deep targeted sequencing reveals mutation burden is associated with gender and clinical out- 
come in lung adenocarcinoma. Oncotarget, 7, 22857-22864.

30. Baak, J.P., Path, F.R., Hermsen, M.A., Meijer, G., Schmidt, J. and Janssen, E.A. (2003) Genomics and proteomics in cancer. Eur. J. Cancer, 39, 1199-1215.

31. Parkin, D.M. (2008) The global burden of urinary bladder cancer. Scand. J. Urol. Nephrol. Suppl., 218, 12-20.

32. American Cancer Society (2009) Cancer Facts \& Figures 2009, American Cancer Society, Atlanta, pp. 1-5.

33. Wilhelm, C.S., Kelsey, K.T., Butler, R., Plaza, S., Gagne, L., Zens, M.S., Andrew, A.S., Morris, S., Nelson, H.H., Schned, A.R., Karagas, M.R. and Marsit, C.J. (2010) Implications of LINE1 methylation for bladder cancer risk in women. Clin. Cancer Res., 16, 1682-1689.

34. Valdés-Mora, F., Gómez del, P.T., Bandrés, E., Cejas, P., Ramírez de Molina, A., Pérez-Palacios, R., Gallego-Ortega, D., García-Cabezas, M.A., Casado, E., Larrauri, J., Nistal, M., González-Barón, M., García-Foncillas, J. and Lacal, J.C. (2009) TWIST1 overexpression is associated with nodal invasion and male sex in primary colorectal cancer. Ann. Surg. Oncol., 16, 78-87.

35. Van der Auwera, I., Bovie, C., Svensson, C., Trinh, X.B., Limame, R., van Dam, P., van Laere, S.J., van Marck, E.A., Dirix, L.Y. and Vermeulen, P.B. (2010) Quantitative methylation profiling in tumor and matched morphologically normal tissues from breast cancer patients. BMC Cancer, 10, 97.

36. Sasaki, K., Natsugoe, S., Ishigami, S., Matsumoto, M., Okumura, H., Setoyama, T., Uchikado, Y., Kita, Y., Tamotsu, K., Sakamoto, A., Owaki, T. and Aikou, T. (2009) Significance of Twist expression and its association with E-cadherin in esophageal squamous cell carcinoma. J. Exp. Clin. Cancer Res., 28, 158.

37. Mikheeva, S.A., Mikheev, A.M., Petit, A., Beyer, R., Oxford, R.G., Khorasani, L., Maxwell, J.P., Glackin, C.A., Wakimoto, H., Gonzalez-Herrero, I., Sanchez-Garcia, I., Silber, J.R., Horner, P.J. and Rostomily, R.C. (2010) TWIST1 promotes invasion through mesenchymal change in human glioblastoma. Mol. Cancer, 9, 194.

38. De Roock, W., Piessevaux, H., De Schutter, J., Janssens, M., De Hertogh, G., Personeni, N., Biesmans, B., Van Laethem, J.L., Peeters, M., Humblet, Y., Van Cutsem, E. and Tejpar, S. (2008) KRAS wild-type state predicts survival and is associated to early radiological response in metastatic colorectal cancer treated with cetuximab. Ann. Oncol., 19, 508-515.

39. Lièvre, A., Bachet, J.B., Le Corre, D., Boige, V., Landi, B., Emile, J.F., Côté, J.F., Tomasic, G., Penna, C., Ducreux, M., Rougier, P., Penault-Llorca, F. and Laurent-Puig, P. (2006) KRAS mutation status is predictive of response to cetuximab therapy in colorectal cancer. Cancer Res., 66, 39923995.

40. Freeman, D.J., Juan, T., Reiner, M., Hecht, J.R., Meropol, N.J., Berlin, J., Mitchell, E., Sarosi, I., Radinsky, R. and Amado, R.G. (2008) Association of K-ras mutational status and clinical outcomes in patients with metastatic colorectal cancer receiving panitumumab alone. Clin. Colorectal Cancer, 7, 184-190.

41. Breivik, J., Meling, G.I., Spurkland, A., Rognum, T.O. and Gaudernack, G. (1994) K-ras mutation in colorectal cancer: relations to patient age, sex and tumour location. $\mathrm{Br}$. J. Can- cer, 69, 367-371.

42. Nüssler, N.C., Reinbacher, K., Shanny, N., Schirmeier, A., Glanemann, M., Neuhaus, P., Nussler, A.K. and Kirschner, M. (2008) Sex-specific differences in the expression levels of estrogen receptor subtypes in colorectal cancer. Gend. Med., 5, 209-217.

43. Campbell-Thompson, M., Lynch, I.J. and Bhardwaj, B. (2001) Expression of estrogen receptor (ER) subtypes and ERbeta isoforms in colon cancer. Cancer Res., 61, 632-640.

44. Wiencke, J.K., Zheng, S., Lafuente, A., Lafuente, M.J., Grudzen, C., Wrensch, M.R., Miike, R., Ballesta, A. and Trias, M. (1999) Aberrant methylation of $\mathrm{p} 16^{\mathrm{INK} 4 \mathrm{a}}$ in anatomic and gender-specific subtypes of sporadic colorectal cancer. Cancer Epidemiol. Biomarkers Prev., 8, 501-506.

45. Dehm, S.M. and Bonham, K. (2004) SRC gene expression in human cancer: the role of transcriptional activation. Biochem. Cell Biol., 82, 263-274.

46. Takemoto, N., Iizuka, N., Yamada-Okabe, H., Hamada, K., Tamesa, T., Okada, T., Hashimoto, K., Sakamoto, K., Takashima, M., Miyamoto, T., Uchimura, S., Hamamoto, Y. and Oka, M. (2005) Sex-based molecular profiling of hepatitis C virus-related hepatocellular carcinoma. Int. J. Oncol., 26, 673-678.

47. Sun, Q.K., Zhu, J.Y., Wang, W., Lv, Y., Zhou, H.C., Yu, J.H., Xu, G.L., Ma, J.L., Zhong, W. and Jia, W.D. (2014) Diagnostic and prognostic significance of peroxiredoxin 1 expression in human hepatocellular carcinoma. Med. Oncol., 31, 786-797.

48. Lehtonen, S.T., Svensk, A.M., Soini, Y., Pääkkö, P., Hirvikoski, P., Kang, S.W., Säily, M. and Kinnula, V.L. (2004) Peroxiredoxins, a novel protein family in lung cancer. Int. J. Cancer, 111, 514-521.

49. Cha, M.K., Suh, K.H. and Kim, I.H. (2009) Overexpression of peroxiredoxin I and thioredoxin1 in human breast carcinoma. J. Exp. Clin. Cancer Res., 28, 93.

50. Yang, L., Li, Y., Hong, H., Chang, C.W., Guo, L.W., LynCook, B., Shi, L. and Ning, B. (2012) Sex differences in the expression of drug-metabolizing and transporter genes in human liver. J. Drug Metab. Toxicol., 3, 1000119.

51. Parkinson, A., Mudra, D.R., Johnson, C., Dwyer, A. and Carroll, K.M. (2004) The effects of gender, age, ethnicity, and liver cirrhosis on cytochrome P450 enzyme activity in human liver microsomes and inducibility in cultured human hepatocytes. Toxicol. Appl. Pharmacol., 199, 193-209.

52. Paris, P.L., Kupelian, P.A., Hall, J.M., Williams, T.L., Levin, H., Klein, E.A., Casey, G. and Witte, J.S. (1999) Association between a CYP3A4 genetic variant and clinical presentation in African-American prostate cancer patients. Cancer Epidemiol. Biomarkers Prev., 8, 901-905.

53. Tanaka, E. (1999) Gender-related differences in pharmacokinetics and their clinical significance. J. Clin. Pharm. Ther., 24, 339-346.

54. Scandlyn, M.J., Stuart, E.C. and Rosengren, R.J. (2008) Sexspecific differences in CYP450 isoforms in humans. Expert Opin. Drug Metab. Toxicol., 4, 413-424.

55. Ou-Yang, D.S., Huang, S.L., Wang, W., Xie, H.G., Xu, Z.H., Shu, Y. and Zhou, H.H. (2000) Phenotypic polymorphism and gender-related differences of CYP1A2 activity in a Chinese population. Br. J. Clin. Pharmacol., 49, 145-151. 
56. Shepherd, F.A., Rodrigues Pereira, J., Ciuleanu, T., Tan, E.H., Hirsh, V., Thongprasert, S., Campos, D., Maoleekoonpiroj, S., Smylie, M., Martins, R., van Kooten, M., Dediu, M., Findlay, B., Tu, D., Johnston, D., Bezjak, A., Clark, G., Santabárbara, P. and Seymour, L.; National Cancer Institute of Canada Clinical Trials Group (2005) Erlotinib in previously treated non-small-cell lung cancer. N. Engl. J. Med., 353, 123-132.

57. Izbicka, E., Streeper, R.T., Michalek, J.E., Louden, C.L., Diaz, A. 3rd and Campos, D.R. (2012) Plasma biomarkers distinguish non-small cell lung cancer from asthma and differ in men and women. Cancer Genomics Proteomics, 9, $27-$ 35.

58. Liao, J. and McCauley, L.K. (2006) Skeletal metastasis: Established and emerging roles of parathyroid hormone related protein (PTHrP). Cancer Metastasis Rev., 25, 559571.

59. Hastings, R.H., Laux, A.M., Casillas, A., Xu, R., Lukas, Z., Ernstrom, K. and Deftos, L.J. (2006) Sex-specific survival advantage with parathyroid hormone-related protein in nonsmall cell lung carcinoma patients. Clin. Cancer Res., 12, 499-506.

60. Parisi, M., Nuttall, R., Naiman, D., Bouffard, G., Malley, J., Andrews, J., Eastman, S. and Oliver, B. (2003) Paucity of genes on the Drosophila $\mathrm{X}$ chromosome showing malebiased expression. Science, 299, 697-700.

61. Ellegren, H. and Parsch, J. (2007) The evolution of sexbiased genes and sex-biased gene expression. Nat. Rev. Genet., 8, 689-698.

62. Williams, T.M. and Carroll, S.B. (2009) Genetic and molecular insights into the development and evolution of sexual dimorphism. Nat. Rev. Genet., 10, 797-804.

63. Mank, J.E. and Avise, J.C. (2009) Evolutionary diversity and turn-over of sex determination in teleost fishes. Sex. Dev., $\mathbf{3}$, 60-67.

64. Connallon, T. and Clark, A.G. (2010) Sex linkage, sex-specific selection, and the role of recombination in the evolution of sexually dimorphic gene expression. Evolution, 64,
3417-3442.

65. Su, A.I., Cooke, M.P., Ching, K.A., Hakak, Y., Walker, J.R., Wiltshire, T., Orth, A.P., Vega, R.G., Sapinoso, L.M., Moqrich, A., Patapoutian, A., Hampton, G.M., Schultz, P.G. and Hogenesch, J.B. (2002) Large-scale analysis of the human and mouse transcriptomes. Proc. Natl. Acad. Sci. U.S.A., 99, 4465-4470.

66. Rong, Z., Fan, T., Li, H., Li, J., Wang, K., Wang, X., Dong, J., Chen, J., Wang, F., Wang, J. and Wang, A. (2017) Differential proteomic analysis of gender-dependent hepatic tumorigenesis in Hras12V transgenic mice. Mol. Cell. Proteomics, 16, 1475-1490.

67. Li, Z., Tuteja, G., Schug, J. and Kaestner, K.H. (2012) Foxa1 and Foxa2 are essential for sexual dimorphism in liver cancer. Cell, 148, 72-83.

68. Liao, Y.J., Liu, S.P., Lee, C.M., Yen, C.H., Chuang, P.C., Chen, C.Y., Tsai, T.F., Huang, S.F., Lee, Y.H. and Chen, Y.M. (2009) Characterization of a glycine N-methyltransferase gene knockout mouse model for hepatocellular carcinoma: Implications of the gender disparity in liver cancer susceptibility. Int. J. Cancer, 124, 816-826.

69. Mato, J.M. and Lu, S.C. (2007) Role of S-adenosyl-L-methionine in liver health and injury. Hepatology, 45, 1306-1312.

70. Cheng, F. (2016) Gender dimorphism creates divergent cancer susceptibilities. Trends Cancer, 2, 325-326.

71. Van Nas, A., Guhathakurta, D., Wang, S.S., Yehya, N., Horvath, S., Zhang, B., Ingram-Drake, L., Chaudhuri, G., Schadt, E.E., Drake, T.A., Arnold, A.P. and Lusis, A.J. (2009) Elucidating the role of gonadal hormones in sexually dimorphic gene coexpression networks. Endocrinology, 150, 12351249.

72. Mittelstrass, K., Ried, J.S., Yu, Z., Krumsiek, J., Gieger, C., Prehn, C., Roemisch-Margl, W., Polonikov, A., Peters, A., Theis, F.J., Meitinger, T., Kronenberg, F., Weidinger, S., Wichmann, H.E., Suhre, K., Wang-Sattler, R., Adamski, J. and Illig, T. (2011) Discovery of sexual dimorphisms in metabolic and genetic biomarkers. PLoS Genet., 7, e1002215. 